\title{
MODEL IMPLEMENTASI INOVASI BIROKRASI STUDI PADA PROGRAM RASKIN POLA PADAT KARYA PANGAN (RASKIN POLA PKP) DI KABUPATEN TIMOR TENGAH UTARA
}

\author{
THE STUDY BUREAUCRATIC INNOVATION IMPLEMENTATION \\ MODEL IN THE RASKIN PROGRAM FOR FOOD LABOR INTENSIVE \\ PATTERNS (RASKIN POLA PKP) IN NORTH CENTRAL TIMOR \\ DISTRICT
}

\author{
Tri Anggraini
}

\author{
Universitas Timor, Jalan Km 09 Kelurahan Sasi, Kefamenanu \\ trianggraini1994@gmail.com
}

\begin{abstract}
Abstrak
Inovasi Pelayanan Publik di berbagai sector menjadi jembatan bagi terpenuhinya kebutuhan dalam pelayanan publik yang prima bagi masyarakat sesuai dengan amanat Undang-Undang Dasar 1945, Pemenuhan kebutuhan pelayanan publik ini adalah bagian dari upaya untuk menyelesaikan persoalanpersoalan dalam kehidupan masyarakat. Salah satunya adalah Program Inovasi Raskin POLA PKP yang merupakan program Inovasi untuk pengembangan sector pertanian di Kabupaten Timur Tengah Utara. Inovasi yang telah menerima penghargaan TOP 99 Inovasi terbaik di Indonesia ini nyatanya telah banyak membawa keuntungan bagi penerima manfaat sehingga inovasi ini terus dikembangkan dan disempurnakan dengan harapan dapat dilaksanakan secara berkelanjutan. Oleh karena itu penelitian ini bertujuan untuk menganalisas proses Implementasi Program Inovasi Raskin POLA PKP. Metode yang digunakan dalam penelitian ini adalah deskriptif kualitatif dengan metode observasi dan wawancara mendalam. Hasil penelitian menunjukkan bahwa Inovasi ini dilakukan melalui tiga tahapan, Penciptaan Ide (generation) terdiri dari Identifikasi Kebutuhan/Masalah, Pendataan, verifikasi Data, Penggambaran Kondisi (tujuan) yang diharapkan Pengembangan dan Pembentukan Ide. Tahap kedua yaitu Penerimaan (acceptance) terdiri dari Perangkulan (sosialisasi/Advokasi), Membangun Kemitraan, Membangun komitmen Stakeholder dan Pengambilan keputusan selanjutnya pada tahap akhir adalah Implementasi (implementation) dari Mengumpulkan Sumber Daya, Penempatan SDM, Pelatihan Teknis/Mekanisme dari Kecamatan sampai desa serta Monitoring dan Evaluasi.
\end{abstract}

\section{Kata Kunci: Implementasi, Inovasi, Birokrasi, Pelayanan Publik}

\begin{abstract}
Public Service Innovations in various sectors become a bridge for meeting the needs of excellent public services for the community in accordance with the mandate of the 1945 Constitution, Fulfilling the needs of public services is part of an effort to resolve problems in people's lives. One of them is the POLA PKP Raskin Innovation Program, which is an innovation program for the development of the agricultural sector in the North Middle East District. This innovation that has received the TOP 99 award The best innovation in Indonesia has in fact brought many benefits to the beneficiaries so that this innovation continues to be developed and refined in the hope that it can be carried out in a sustainable manner. Therefore this study aims to analyze the process of implementing the Raskin Innovation Program for the POLA PKP. The method used in this research is descriptive qualitative
\end{abstract}


method of observation and in-depth interviews. The results showed that this innovation was carried out in three stages, Idea Generation (generation) consisting of Identification of Needs / Problems, Data Collection, Data Verification, Describing Conditions (objectives) expected Development and Formation of Ideas. The second stage is acceptance which consists of embracing (socialization / advocacy), building partnerships, building stakeholder commitment and making the next decision in the final stage is the implementation of gathering resources, placement of human resources, technical I mechanism training from sub-district to village as well as Monitoring and Evaluation.

\section{Keywords: Implementation, Innovation, Bureaucracy, Public Service}

\section{PENDAHULUAN}

Tatanan kehidupan masyarakat yang terus berkembang juga dibarengi dengan harapan dan tantangan global. Oleh karenanya, upaya peningkatan pelayanan publk yang sesuai dengan harapan masyarakat terus digalakkan. Hal ini dibarengi dengan konsep dasar bahwa negara berkewajiban melayani setiap warga negara dan penduduk untuk memenuhi hak dan kebutuhan dasarnya dalam kerangka pelayanan publik yang merupakan amanat Undang-Undang Dasar Negara Republik Indonesia Tahun 1945. Saat ini, pelayanan publik menjadi tolak ukur utama kinerja pemeintah yang dapat secara gamblang terlihat, Masyarakat dapat menilai langsung kinerja pemerintah berdasarkan pelayanan yang diterimanya. Untuk itu, kualitas pelayanan publik menjadi bagian yang sangat mendasar yang harus terus ditingkatkan. Melihat kondisi ini, KemenPAN RB menerapkan kebijakan pada tahun 2014 adalah tahun inovasi pelayanan publik. Seluruh instansi pemerintah, baik di pusat maupun daerah dituntut untuk mencipatakan inovasiinovasi yang berakar pada penyelesaianpenyelesaian masalah-masalah dalam pelayanan publik.

Inovasi sendiri dimaknai dengan 2 makna yaitu ide baru dan perubahan (Sorensen, E., \& Torfing, 2011). Mulgan dan Albury mendefinisikan bahwa inovasi merupakan ide-ide baru yang diimplementasikan atau lebih tepatya inovasi yang berhasil adalah penciptaan dan implementasi dari proses, produk, pelayanan, dan mekanisme penyampian layanan yang baru untuk menghasilkan peningkatan efisiensi, efektivitas, dan kualitas yang signifikan (Mulgan, G., \& Albury, 2003). Definisi yang lebih lengkap disampaikan oleh Van Den Ban dan Hawkins (1996) yang menyatakan: an innovation is an idea, method, or object which is regarded as new by individual, but which is not always the result of recent research. 
Pengembangan Inovasi diberbagai lini terus digalakkan, salah satunya pada sektor pertanian yang menjadi sektor yang diyakini dapat terus diandalkan sebagai suatu sektor yang mampu memcahkan masalah-masalah keterbelakangan negaranegara berkembang. Lahirnya Inovasi dalam pelayanan publik sendiri tidak semata karena tuntutan dari atasan tetapi hendaknya lahir sebagai upaya pemecahan masalah dalam sektor pubik. Salah satunya Inovasi Pelayanan Publik yang terjadi di Kabupaten Timur Tengah Utara. Kabupaten Timur Tengah Utara sendiri merupakan salah satu daerah di Kawasan Perbatasan RI-RDTL dengan potensi pertanian lahan kering yang sangat potensial yaitu seluas $187.650 \mathrm{Ha}$. Kondisi lahan kering yang tidak dimaksimalkan dengan baik ini berdampak pada rendahnya hasil pertanian lahan kering di daerah ini. Kondisi lahan kering yang tidak dimanfaatkan sehingga tidak menjadi lahan kering yang produktif. Keadaan pertanian di Kabupaten Timor Tengah Utara merupakan pertanian tradisional yang didominasi dengan pola tebas bakar dan perladangan berpindah. Kondisi ini menyebabkan degradasi lahan yang cukup besar yang ditandai dengan tingkat kesuburan tanah yang rendah dan erosi permukaan tanah yang tinggi. Rata- rata penduduk desa merupakan petani yang hidup di bawah garis kemiskinan. Padahal, jika dapat dimaksimalkan dengan baik, potensi luas lahan kering yang ada di Kabupaten Timur Tengah Utara ini dapat memberikan manfaat bagi seluruh masyarat dengan mayoritas petani. Permasalahan ini menjadi alasan utama Pemerintah Kabupaten Timur Tengah Utara dalam menciptakan Inovasi bagai pengembangan sektor pertanian.

Kondisi inilah yang mendorong pemerintah Kab.TTU meluncurkan Inovasi yang diberi nama Raskin Pola PKP. Program Raskin Pola PKP merupakan terobosan yang dilakukan oleh Pemerintah Kab. TTU untuk mengatasi masalah kemiskinan dan ketidakcukupan pangan dengan mengkonversi raskin nasional mengharuskan Masyarakat yang menjadi Rumah Tangga Sasaran penerima program raskin nasional untuk mengelola lahan sendiri dengan Pola Padat Karya Pangan. Program ini berbeda dari program raskin nasional, secara nasional Rumah Tangga Sasaran (RTS) membayar harga tebus raskin sebesar Rp. 1.600,/kg sedangkan melalui Raskin Pola PKP masyarakat menerima raskin secara gratis dengan kewajiban mengerjakan kebunnya sendiri seluas 0,25 Ha per tahun. Pelaksanaan raskin Pola PKP dimaksudkan untuk 
memanfaatkan lahan tidur (lahan basah dan lahan kering potensial), mengurangi sistem tebas bakar dan perladangan berpindah, memperkecil erosi permukaan dan menjaga kelestarian lingkungan melalui olah jalur dan olah lubang (konservasi lahan) dan pembuatan terasering yang tersebar pada 194 Desa/Kelurahan yang tersebar di 24 Kecamatan.

Inovasi yang telah menerima penghargaan TOP 40 Inovasi pelayanan publik terbaik di Indonesia pada tahun 2018 (MENPANRB, 2018) ini nyatanya telah banyak membawa keuntungan bagi penerima manfaat program Raskin Pola PKP ini. Selain mendorong masyarakat untuk pertanian secara menetap Pola Padat Karya Pangan juga mendorong masyarakat menerapkan pertanian berkelanjutan. Perubahan pola pertanian yang tradisional menjadi pola pertanian dengan Padat Karya Pangan berdampak pada Adanya perubahan perilaku masyarakat yang sebelumnya melakukan pengolahan kebun berpindah dengan pola tebas bakar, menjadi masyarakat yang peduli terhadap pengelolaan kebun secara menetap dan berkelanjutan. Inovasi selalu berhubungan erat dengan ide-ide baru yang bermanfaat (Anggraini, 2019). Sistem pertanian dengan cara menetap ini berdampak pada lahan pertanian mampu berproduksi secara stabil sepanjang tahun sehingga berdampak pada kestabilan ekonomi petani karena tidak terjadinya pasang surut komoditas yang terlalu signifikan. Selain itu keuntungan lain perubahan pola pertanian dengan Padat Karya Pangan ini juga dapat mencegah kerusakan lingkungan dan memperhatikan penggunaan pupuk secara alami karena para petani meninggalkan pola tebas bakar yang selama ini digunakan. Tidak hanya itu, Pola PKP ini juga memberikan keuntungan lain, yaitu adanya peningkatan pendapatan petani, dalam data Dinas Pertanian Kab.TTU pendapatan petani pada tahun 2010 sebesar Rp. 4.081.912,00 menjadi Rp. 5.567.626,00 di tahun 2016.

Oleh karenanya peneliti tertarik untuk melihat bagaimana implementasi inovasi Program Raskin Pola PKP di Kabupaten TTU. Penelitian ini mengacu pada teori yang mengungkapkan bahwa Inovasi dipandang sebagai suatu proses yang dikemukakan Shepard (1967) bahwa Inovasi terdiri dari tiga tahapan proses, yaitu penciptaan (generation); penerimaan (Acceptance) dan Impelementasi (Implementation). Inovasi merupakan penciptaan, penerimaan, dan implementasi ide atau pendekatan baru terhadap isu atau masalah tertentu (Bland et al., 2010). Penulis memandang teori ini telah memadai untuk menjelaskan Model Inovasi Program 
Raskin Pola Padat Karya Pangan (RASKIN POLA PKP) di Kab.TTU.

\section{METODE PENELITIAN}

Penelitian ini dilakukan menggunakan penelitian kualitatif dengan alasan bahwa metode ini ini diekspektasikan mampu mendeskripsikan analisis berupa teks atau narasi secara mendalam (Creswell, 2014). Dengan melihat fenomena yang akan dikaji metode studi kasus dipilih diawali dengan teoriteori yang spesifik. Sedangkan metode yang digunakan dalam penelitian ini adalah deskriptif analitis. Pemilihan pendekatan kualitatif ini juga dinilai penulis lebih tepat digunakan untuk memahami dan menggambarkan kondisi lapangan, fenomena-fenomena Program inovasi Raskin Pola PKP. Teknik pengumpulan data dalam penelitian ini dilakukan menggunakan teknik pengumpulan data berupa studi kepustakaan dan studi lapangan. Studi lapangan dilakukan diantaranya dengan observasi dan wawancara mendalam. Observasi yaitu mengamati kegiatan yang dilakukan dalam proses Inovasi, sedangkan, wawancara mendalam adalah proses memperoleh keterangan untuk penelitian dengan cara tanya jawab sambal bertatap muka antara pewawancara dengan informan, dengan atau tanpa mengggunakan pedoman wawancara (Bungin, 2007). Peneliti membuat pedoman wawancara namun dalam proses menggali informasi, peneliti mengajukan pertanyaan lain yang tidak ada dalam pedoman wawancara untuk mempertajam dan memperjelas pertanyaan sebelumnya.

Pemilihan Narasumber dilakukan secara purposive yaitu orang-orang yang memiliki kecukupan pengetahuan dan mampu menjelaskan keadaan yang sebenarnya sesuai dengan kebutuhan penelitian. Kepala Dinas Pertanian, Sekretaris Dinas Pertanian dan stakeholder lain pendukung dalam Program Inovasi Raskin Pola PKP. Selanjutnya hasil wawancara ditranskipkan menjadi analisis kualitatif menggunakan 3 alur secara bersamaan, yaitu reduksi data, penyajian data, dan penarikan kesimpulan. Reduksi data dilakukan secara terus menerus selama kegiatan untuk melihat secara langsung fenomena yang terjadi dalam Program inovasi Raskin Pola PKP. Sedangkan penyajian sebagai sekumpulan informasi tersusun yang memberi kemungkinan adanya penarikan kesimpulan dan pengambilan tindakan. Pada penarikan kesimpulan dilakukan pula verifikasi dengan proses berpikir kembali dan 
meninjau ulang catatan-catatan lapangan (Miles B, Mathew, 1992)

\section{HASIL PENELITIAN}

Program Inovasi RASKIN POLA PKP mulai dikembangkan sejak bulan September 2011 di Kabupaten Timor Tengah Utara. Sebagai konsep yang baru dan program strategis bagi Dinas Pertanian Kabupaten Timor Tengah Utara. Inovasi Raskin POLA PKP ini bagian dari upaya yang dilakukan pemerintah daerah untuk memaksimalkan pengelolaan lahan kering dan lahan basah guna mencukupi kebutuhan pangan dan meningkatkan pendapatan masyarakat. Pemenuhan kebutuhan pangan tersebut dilakukan dengan melakukan perluasan lahan garapan pertanian baik dari lahan kering maupun lahan basah. Perluasan lahan pertanian ini juga dibarengi dengan perbaikan sister budidaya pertanian sehngga produktivitas dari lahan pertanian juga dapat maksimal. Upaya mendorong perluasan lahan pertanian ini dilakukan dengan memberikan konpensasi beras raskin bagi masyarakat penerima manfaat tanpa harus membayar uang tebusan yang biasanya dibayar Rp. 1.600/kg dari harga normal Rp. $7.300 / \mathrm{kg}$.

Pada tahun 2010 sebelum inovasi Raskin Pola Padat Karya Pangan (Raskin
Pola PKP) dilaksanakan, jumlah penduduk di Kabupaten Timor Tengah Utara sebanyak 229.803 jiwa atau 53.081 KK, dengan jumlah masyarakat petani sebanyak 60.497 jiwa dan jumlah keluarga miskin sebanyak 65,62 \% atau $34.832 \mathrm{KK}$. Hal ini menyebabkan terdapat banyak permasalahan yang dihadapi antara lain : (1). Program peningkatan kesejahteraan rakyat yang dilakukan Pemerintah Pusat melalui Beras Miskin (RASKIN) gagal menurunkan angka kemiskinan di Kabupaten TTU yang mencapai 65,62\%; (2). Masyarakat petani yang menjadi Rumah Tangga Sasaran penerima program raskin nasional menerima beras raskin dengan ganti uang atau membayar beras dengan harga murah (Rp. 1.600/kg dari harga normal Rp. 7.300/kg) tanpa mengerjakan sesuatu; (3). Lahan kering potensial seluas $187.650 \mathrm{Ha}$ dan lahan basah potensial seluas 3.123 Ha tidak diolah secara baik oleh masyarakat dan dibiarkan dalam kondisi bero, sebagai hutan semak belukar saja; (4). Produksi dan produktivitas lahan pertanian yang rendah (Produksi tanaman pangan mencapai 172.012 ton dan produktivitas tanaman pangan sebanyak 3,73 ton/ha pada tahun 2010); (5). Pendapatan masyarakat masih sangat rendah yakni rata-rata $\mathrm{Rp}$. 4.081.912,00 per tahun atau Rp. 340.159,00 
per bulan; (6). Pengerjaan kebun dilakukan dengan pola tebas bakar dan perladangan berpindah tanpa teknik budidaya yang baik sehingga menyebabkan kerusakan lahan pertanian, tingginya erosi permukaan dan kerusakan hutan.

Permasalahan ini menjadi latar belakang utama lahirnya Program Raskin POLA PKP. Upaya dalam mengimplementasikan Program Raskin Pola PKP ini diawali melalui sosialisasi yang dilakukan oleh pemerintah Kabupaten Timur Tengah Utara kepada stakeholder terkait. Sosialisasi awal dilakukan kepada Tim Koordinasi Kabupaten dengan pembahasan dan menetapkan kebijakan pengelolaan Raskin dengan pola PKP dari tahapan persiapan sampai dengan evaluasi dengan memastikan arah pelaksanaan pengelolaan Raskin pola PKP sesuai dengan tujuan yang ingin dicapai yaitu membangun sumber daya produktif agar dapat menjadi modal untuk mewujudkan kedaulatan pangan bagi keluarga miskin. Sosialisasi tahap kedua dilakukan kepada tim koordinasi kecamatan dengan mensosialisasikan kebijakan dan mekanisme pengelolaan Raskin dengan pola PKP kepada aparatur Desa/Kelurahan dan pihak lain yang berada di dalam wilayah yang bersangkutan serta pembinaan terhadap pelaksanaan pengelolaan Raskin dengan pola PKP. Sosialisasi terakhir dilakukan langsung kepada masyarakat melalui tim koordinasi desa dan dilanjutkan dengan pembentukan Komite Desa/Kelurahan. Tidak hanya itu, sebagai upaya menggalang dukungan serta komitmen para stakeholder dalam upaya pengembangan Program Inovasi Raskin Pola PKP ini. Pemerintah Kabupaten TTU juga membangun kemitraan Bersama LSM. Mitra yang tergabung antara lain Mitra Tani Mandiri, An Feot Ana, Timor Membangun, Bina Swadaya dan YABIKU, sebagai pendamping lapangan serta membangun kemitraan dan kolaborasi dengan lembaga Berbadan Hukum Penyedia dan Penyalur Raskin (Bulog).

Proses lainnya, pada tahap terakhir ini juga dilakukan proses advokasi masyarakat petanai di 175 Desa/Kelurahan yang tersebar di 24 Kecamatan yang ada diwilayah Kabupaten Timur Tengah Utara. Komitmen lain juga berasal dari 24 camat dan 175 Kepala Desa/Lurah yang melibatkan tokoh masyarakat adat, tokoh agama, tokoh perempuan dan tokoh pemuda.

Komitmen ini dapat dilihat dari kesungguhan semua tingkatan Pemerintah daerah Kab.TTU, Komitmen ini diinisiasi oleh Bupati Kabupaten TTU setelah mengkaji kendala atau faktor-faktor 
penyebab Program Raskin Nasional dari Pemerintah Pusat gagal menurunkan angka kemisikinan dan perbaikan pendapatan masyarakat Timor Tengah Utara melalui komitemen ini Bupati selaku inisiator lahirnya Inovasi ini Mencanangkan Panca Program Strategis yang termuat dalam Rencana Pembangunan Jangka Menengah Daerah Kabupaten TTU dengan menempatkan pengembangan pertanian sebagai prioritas utama guna mengurangi angka kemiskinan, mencegah kerusakan lingkungan, mewujudkan ketahanan pangan dan peningkatan pendapatan tunai keluarga tani. Komitmen ini juga diejawatakan dalam Peraturan Daerah Kabupaten TTU Nomor 4 Tahun 2011 Tentang Rencana Pembangunan Jangka Menengah Daerah (RPJMD) Kabupaten TTU 2011-2015 dan Peraturan Daerah Kabupaten TTU Nomor 2 Tahun 2016 Tentang Rencana Pembangunan Jangka Menengah Daerah (RPJMD) Kabupaten TTU 2016-2021.

Dalam Penerapannya, Inovasi ini menggunakan anggaran yang berasal dari anggaran Raskin dari Pemerintah Pusat serta anggaran yang berasal dari pemerintah Kabupaten Timur Tengah Utara setidaknya Pemerintah Kab.TTU telah menganggarkan Subsidi Beras Miskin dari Pemerintah Pusat mulai Tahun 2012 sampai Tahun 2017 sebesar Rp. 130.926.834.000 dan anggaran subsidi beras dari Pemerintah Kabupaten Timor Tengah Utara mulai Tahun 2012 sampai Tahun 2017 sebesar Rp. 36.751.392.000, adanya peningkatan Jumlah Rumah Tangga Miskin tahun 2017 disebabkan karena pengalihan status 22 kelurahan menjadi sehingga ketika dilakukan validasi angka kemiskinan antara pemerintah Kabupaten TTU dengan BPS TTU terjadi penambahan jumlah angka kemiskinan, dengan rincian pada tabel 1 .

Tabel 1

\begin{tabular}{|c|c|c|c|c|}
\hline \multicolumn{5}{|c|}{$\begin{array}{c}\text { Jumlah RTM Raskin dan Jumlah } \\
\text { Pemerintah }\end{array}$} \\
\hline Thn & $\begin{array}{l}\text { Juml } \\
\text { ah } \\
\text { RTS } \\
\text { PKP }\end{array}$ & $\begin{array}{c}\text { Jumlah } \\
\text { RTM } \\
\text { Raskin } \\
\text { Nasional }\end{array}$ & $\begin{array}{l}\text { Anggaran } \\
\text { Subsidi oleh } \\
\text { Pemerintah } \\
\text { Pusat } \\
\text { (Rp.000) }\end{array}$ & $\begin{array}{c}\text { Anggaran } \\
\text { Subsidi } \\
\text { oleh } \\
\text { Pemerintah } \\
\text { Kabupaten } \\
\text { (Rp.000) }\end{array}$ \\
\hline 2012 & $\begin{array}{c}48.4 \\
34 \\
\end{array}$ & 26.558 & 27.248 .508 & 7.648 .704 \\
\hline 2013 & $\begin{array}{c}48.4 \\
34\end{array}$ & 19.814 & 20.329 .164 & 5.706 .432 \\
\hline 2014 & $\begin{array}{c}48.4 \\
34\end{array}$ & 19.814 & 20.329 .164 & 5.706 .432 \\
\hline 2015 & $\begin{array}{c}48.4 \\
34\end{array}$ & 19.814 & 20.329 .164 & 5.706 .432 \\
\hline 2016 & $\begin{array}{c}48.4 \\
34\end{array}$ & 19.814 & 20.329 .164 & 5.706 .432 \\
\hline 2017 & $\begin{array}{c}48.4 \\
34\end{array}$ & 21.795 & 22.361 .670 & 6.276 .960 \\
\hline $\begin{array}{l}\text { JUM } \\
\text { LAH }\end{array}$ & & 127.609 & 130.926 .834 & 36.751 .392 \\
\hline
\end{tabular}

Dalam tahap Implementasi, Program Inovasi Raskin Pola PKP ini dimulai dengan penentuan Sumber Daya. Sumber daya menjadi actor penggerak 
paling penting dalam upaya pelaksanaan suatu program sehingga salah satu factor penting dalam implementasi kebijakan adalah sumber daya. Walaupun isi kebijakan sudah dikomunikasikan secara jelas dan konsisten, tetapi apabila implementator kekurangan sumber daya untuk melaksanakan, implementasi tidak akan berjalan efektif. Sumber daya yang dimaksudkan adalah control terhadap sumber dana; keseimbangan antara

pembagian anggaran \& kegiatan program; ketepatan alokasi anggaran; pendapatan yang cukup untuk pengeluaran; dukungan pemimpin politik. Pusat dukungan pemimpin local; komitmen birokrasi (Subarsono, 2005)

\section{Sumber Daya dalam Program} Raskin POLA PKP ini terdiri dari Sumber Daya Manusia dan Sumber Daya Keuangan. Sumber Daya Manusia dapat dilihat dari Struktur pelaksana pengelolaan Raskin dengan pola PKP dari tingkat Kabupaten sampai desa/kelurahan pada gambar 1.

Dari struktur pelaksana program tersebut dapat diketahui bahwa: (1). Bupati dan Wakil Bupati Timor Tengah Utara sebagai inisiator, sekaligus mengawasi seluruh proses pelaksanaan Program Raskin Pola Padat Karya Pangan (PKP),

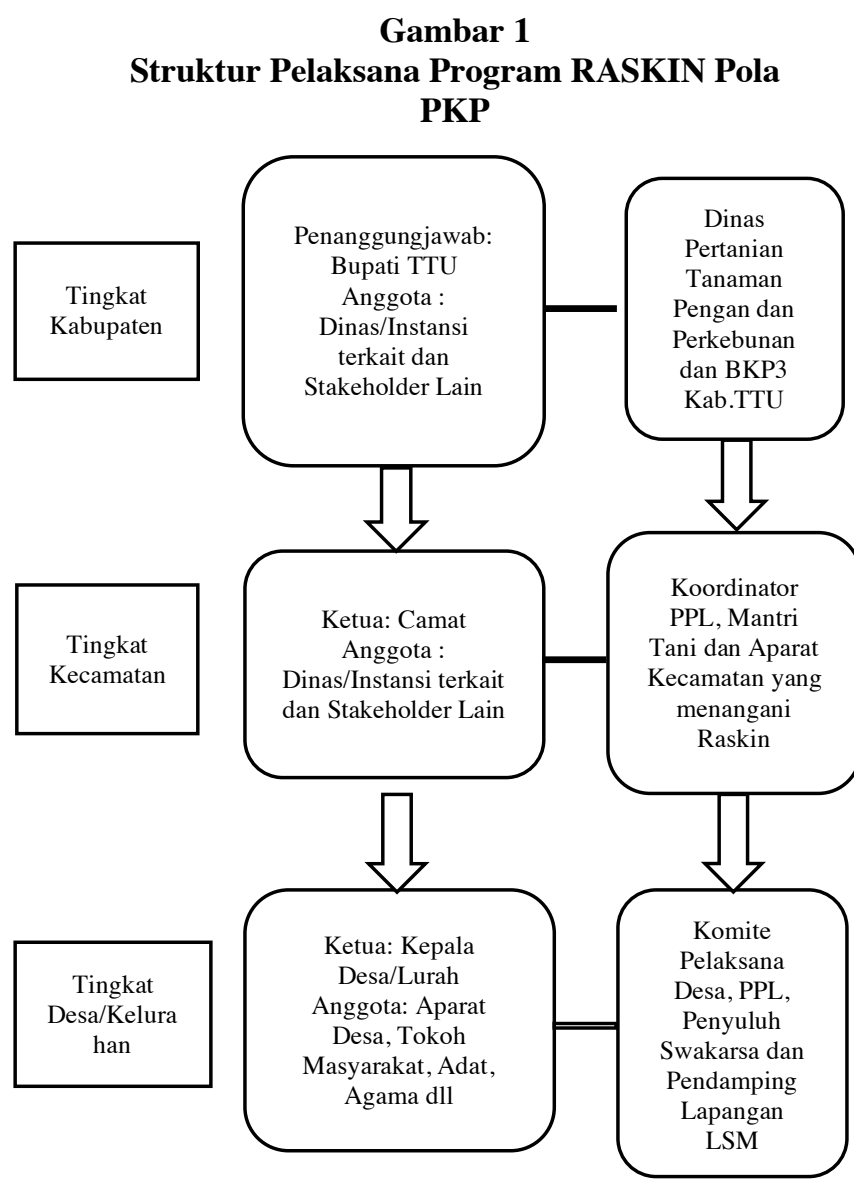

Sumber : Data Sekunder Penulis, 2020

dan memastikan bahwa semua masyarakat miskin terlibat dalam program tersebut; (2). Kepala Dinas Pertanian Kabupaten Timor Tengah Utara sebagai penanggung jawab teknis pelaksanaan program; (3).Para camat dari 24 kecamatan, para kepala desa di 175 desa/kelurahan, bersama perangkat kerjanya yang memberikan dukungan; (4). 156 PPL, 25 PPSD dan 24 Mantri Tani sebagai pelaksana teknis di lapangan bersama komite desa; (5). Tim Koordinasi Kabupaten, Tim Koordinasi Kecamatan, Tim Koordinasi Desa, Tim Teknis Kabupaten, Tim Teknis Kecamatan dan 
Tim Teknis Desa. Berikut Struktur pelaksana pengelolaan Raskin dengan pola PKP dari tingkat Kabupaten sampai desa/kelurahan:

Pelaksanaan kegiatan dimulai sejak bulan Januari sampai dengan Bulan Desember Waktu efektif yang dibutuhkan untuk mengimplementasikan satu tipe kegiatan yakni selama 2 (dua) bulan. Dalam setahun beras didistribusikan sebanyak 2 kali yaitu periode pertama untuk pekerjaan tahap I, II dan III (bulan Januari s/d Juni) dan periode kedua untuk pekerjaan tahap IV, V dan VI (bulan Juli s/d Desember). Pendistribusian Raskin Pola PKP periode pertama dilakukan pada bulan Juli-bulan Agustus dan pendistribusian periode kedua pada bulan Oktober-bulan November. Penetapan periode dimaksud dilaksanakan berdasarkan beberapa pertimbangan spatial sebagai berikut: (1). Bahwa dalam bulan April sampai dengan bulan Juni masyarakat masih memiliki persediaan pangan yang memadai karena baru selesai panen; (2). Untuk meminimalisir budaya lokal masyarakat yang senantiasa melaksanakan ritual-ritual adat yang bersifat pemborosan apabila memiliki ketersediaan pangan yang melimpah; (3). Sebagai salah satu metode untuk merubah pola hidup masyarakat dari pola hidup konsumtif kepada pola hidup ekonomis dalam arti masyarakat diajak untuk menghargai cucuran keringatnya sendiri dan bukan sekedar mempertaruhkan gengsi sosial; (4). Untuk mengatasi kekurangan pangan dalam masa-masa paceklik, terutama di awal musim tanam pada bulan November dan bulan Desember bahkan sampai dengan awal musim panen pada bulan Maret tahun berikutnya.

Monitoring dan Evaluasi ini adalah Sistem yang diterapkan untuk memantau kemajuan dan mengevaluasi pelaksanaan Program Raskin Pola PKP yakni dengan melakukan monitoring dan evaluasi secara periodik atau sesuai kebutuhan yang dilaksanakan secara terpadu dengan metode kunjungan lapangan, diskusi lapangan dan rapat koordinasi, tujuannya yakni untuk mengetahui ketepatan dan kepastian realisasi pelaksanaan Pengelolaan Raskin Pola Padat Karya Pangan (Raskin Pola PKP) dan permasalahannya. Tim monitoring harus membuat laporan sebagai dasar untuk pengambilan keputusan, yang dilaksanakan secara terpadu dengan melibatkan Tim Koordinasi dan Tim Teknis Kabupaten dan Kecamatan.

\section{PEMBAHASAN}

Shepard (1967) mengungkapkan bahwa Inovasi dipandang sebagai sebuah proses yang terdiri dari tiga tahapan proses, yaitu penciptaan (generation); penerimaan 
(acceptance) dan impementasi (implementation) ide. Oleh karenanya, Inovasi merupakan penciptaan, penerimaan, dan implementasi ide atau pendekatan baru terhadap isu atau masalah tertentu (Bland et al., 2010). tahapan penciptaan Ide, ada bebelangka yang dilakukan, yaitu pengenalan terhadap kebutuhan atau masalah yang dihadapi; pengumpulan informasi; intervretasi dan evaluasi informasi; dan pembentukan sikap. Pada tahap penerimaan, kegiatan yang dilakukan dalam melakukan studi kelayakan; adaptasi/modifikasi; penetapan nilai dan tujuan yang hendak dicapai; pembangunan koalisi; demonstrasi dan persuasi; serta pengambilan keputusan. Dan pada tahap implementasi, langka yang dilakukan diantaranya adalah mengumpukan sumber daya; penempatan SDM; melakukan pelatihan; membangun struktur dan mekanisme kerja; melaukan monitoring dan evaluasi (Bland et al., 2010).

Dalam Inovasi Raskin Pola PKP ini diawali pada tahapan penciptaan ide, dengan empat Langkah yang dilakukan, yaitu pertama, Identifikasi Kebutuhan masalah. Inovasi akan menjadi kebutuhan petani apabila inovasi tersebut dapat memecahkan masalah yang sedang dihadapi petani. Sehingga identifikasi masalah secara benar menjadi sangat penting (Wahyuni, 2000). Dalam Langkah pertama, berupa Identifikasi kebutuhan dan masalah ini, pemerintah Kabupaten Timur Tengah Utara sekaligus melakukan Langkah kedua dalam pencipataan ide berupa, pendataan dan memverifikasi data Rumah Tangga Miskin di Kabupaten TTU. Salah satu ukuran kemiskinan yakni ketidakmampuan masyarakat memenuhi kebutuhan dasar sandang, pangan dan papan. Pada tahap ketiga Pemerintah Kabupaten TTU menggambarkan kondisi (tujuan yang diharapakan dengan mengacu kepada identifikasi kebutuhan dan masalah yang ada di Kab.TTU. Mengacu kepada identifikasi kebutuhan dan masalah, dapat digambarkan sebagai berikut: Pengelolaan lahan kering dan lahan basah perlu dilakukan secara optimal guna mencukupi kebutuhan pangan dan meningkatkan pendapatan masyarakat; (2). Untuk memenuhi kebutuhan pangan maka perluasan lahan kering atau lahan basah perlu dilakukan dengan sistem budidaya pertanian yang baik sehingga produktivitas dapat meningkat; (3). perlu dirubah pola pemberiannya yakni bukan dengan ganti uang melainkan dengan ganti kerja, caranya yakni masyarakat penerima raskin mengusahakan lahan pertanian yang ada guna menambah ketersedian pangan 
keluarga; (4). pembiaran terhadap pola tebas bakar dan perladangan berpindah akan menyebabkan kerusakan lingkungan dan bencana bagi masyarakat sehingga perlu dilakukan perbaikan model kebun menetap dengan sistem wanatani yang mengutamakan pelestarian lingkungan.

Kondisi tersebut di atas, menjadi faktor penyebab tingginya angka kemisikinan dan kerusakan lingkungan di Kabupaten Timor Tengah Utara. Peran pemerintah dalam menurunkan angka kemiskinan dan perbaikan lingkungan sudah cukup banyak dengan menggelontorkan berbagai macam program, namun sayangnya belum ada yang bisa menjadi daya ungkit yang tajam untuk menurunkan angka kemiskinan dan kerusakan lingkungan, buktinya penduduk miskin masih ada dan kerusakan lingkungan masih terjadi. Oleh karena itu, dibutuhkan sebuah program yang melibatkan semua elemen masyarakat untuk mengentaskan kemiskinan dan mencegah kerusakan lingkungan menggunakan model kebun menetap sistem wanatani yang disebut Inovasi RASKIN POLA PADAT KARYA PANGAN (PKP).

Dalam Proses penerimanaan Program Raskin Pola PKP ini diawali pada tahap Perangkulan Sosialiasi dan Advokasi. Tahap Sosialisasi menjadi tahapan yang sangat penting, dengan sosialisasi yang sudah dilakukan, memberikan kesempatan bagi masyarakat sebagai pengguna manfaat untuk mengamati serta memahami prosedur Inovasi Raskin Pola PKP. Tahap awal yang dilakukan pemerintah sebelum mengimplementasikan program Inovasi Raskin Pola PKP ini adalah dengan mensosialisasikan Program Inovasi Raskin Pola PKP ini kepada masyarakat melalui pola sosialisasi secara berjenjang. Sosialisasi yang dilakukan secara berjenjang ini adalah salah satu upaya yang dilakukan untuk dapat memberikan gambaran secara detail kepada masyarakat dan pemangku kepentingan terkait Inovasi Raskin pola PKP ini untuk lebih memahami dan mengamati Program Inovasi Raskin Pola PKP ini. Proses sosialisasi pada tahap terakhir ini juga dilakukan proses advokasi masyarakat petani di 175 Desa/Kelurahan yang tersebar di 24 kecamatan yang ada di wilayah Kabupaten TTU.

Membangun komitmen dengan para Camat, para Kepala Desa/Lurah, karena merekalah pemilik masyarakat serta melibatkan tokoh masyarakat, tokoh adat dan tokoh agama, tokoh perempuan dan tokoh pemuda, caranya melakukan sosialisasi kepada seluruh stakeholders yang ada di kecamatan, dan desa/kelurahan tentang pelaksanaan Program Raskin Pola 
Padat Karya Pangan. Upaya melibatkan banyak stakeholder ini diyakini sebagai bentuk upaya untuk memaksimalkan peran masing-masing stakeholder sehingga kebutuhan dalam pelayanan Program Inovasi RASKIN Pola PKP ini dapat terpenuhi dengan baik. Maka, tidak hanya diperlukan kemitraan namun juga perlu adanya komitmen bersama bagi seluruh stakeholder yang telah sepakat terlibat untuk berkomitmen Bersama dalam menyukseskan Program Raskin Pola PKP ini.

Komitmen organisasi sebagai keinginan yang kuat yang dimilki oleh seorang pegawai agar dapat bertahan sebagai anggota dari organisasi, kemauan untuk bekerja keras sesuai dengan tujuan organisasi dan keyakinan yang kuat yang dimilki dalam menerima setiap nilai dan tujuan yang terdapat dalam organisasi (Luthans, 2012)

Komitmen lain juga berasal dari 24 camat dan 175 kepala Desa/Lurah yang melibatkan tokoh masyarakat adat, tokoh agama, tokoh perempuan dan tokoh pemuda. Komitmen ini dibangun melalui penandatangan kontrak kerja antara Bupati Timor Tengah Utara dengan pada Camat se-Kabupaten Timor Tengah Utara setiap tahun terkait pelaksanaan Program Raskin Pola PKP. Selain Peraturan Bupati TTU tentang pelaksanaan Raskin Pola PKP setiap tahun. Upaya membangun mitra dan komitemen para stakeholder ini sebagai bentuk dukungan dalam penerapan program Inovasi Raskin Pola PKP. Sehinggga akhirnya diperolehlah kesepakatan diantara stakeholder terkait untuk mendukung dan berkomitmen menerapkan Program Inovasi Raskin Pola PKP.

Dalam Penerapannya, Inovasi ini tentu memerlukan dukungan finansial, Pemerintah Kabupaten Timur Tengah Utara telah menggangarkan subsisdi beras Raskin bagi masyarakat penerima manfaat dari Raskin Pola PKP, setidaknya Pemerintah Kabupaten Timur Tengah Utara telah menganggarkan Subsidi Beras Miskin dari Pemerintah Pusat mulai Tahun 2012 sampai Tahun 2017 sebesar Rp. 130.926.834.000 dan anggaran subsidi beras dari Pemerintah Kabupaten Timor Tengah Utara mulai Tahun 2012 sampai Tahun 2017 sebesar Rp. 36.751.392.000.

Sebagai upaya optimalisasi Sumber Daya Manusia yang terlibat dalam Program Inovasi Raskin POLA PKP ini. Pemerintah Kab.TTU juga melakukan pelatihan teknis dan mekanisme yang dilakukan mulai dari Tingkat Kecamatan Hingga Desa. Tahap terakhir dalam Impelementasi ini adalah Monitoring dan Evaluasi. Hasil monitoring 
dan evaluasi dibahas secara berjenjang dalam Rapat Tim Koordinasi Desa/Kelurahan, Kecamatan dan Tim Koordinasi Kabupaten sesuai dengan lingkup dan

bobot permasalahannya untuk
ditindaklanjuti serta sebagai bahan
pertimbangan dalam penyempurnaan
program. Dalam penelitian (Anggraini, Tri;
Seran, 2020) diungkapkan bahwa Impelmentasi suatu program, dapat dilihat dari keberhasilan pelaksanaan dilapangan, semakin banyak masyarakat yang merasakan keuntungan dari Inovasi maka semak tinggi pula upaya yang harus dilakukan pemerintah untuk terus melakukan perbaikan melalui keluluasaan dalam penyempaian krtik, saran dan keluhan sebagai upaya pengembangan dan perbaikan dari Inovasi Raskin Pola PKP ini. Evaluasi wajib dilakukan oleh Tim Koordinasi Desa/Kelurahan setiap saat sesuai kondisi masing-masing desa/kelurahan. Setiap bulan Oktober dalam tahun, diadakan Rapat Evaluasi antara Bupati dengan seluruh Camat dan Kepala Desa/Lurah se-Kabupaten TTU yang membahas salah satu di dalamnya yakni keberhasilan maupun kendala yang dihadapi dalam pelaksanaan kegiatan Raskin Pola Padat Karya Pangan (Raskin Pola PKP). Model Implementasi Program
Inovasi Raskin Pola PKP digambarkan pada gambar 2 .

Gambar 2

Model Implementasi Inovasi Raskin POLA PKP

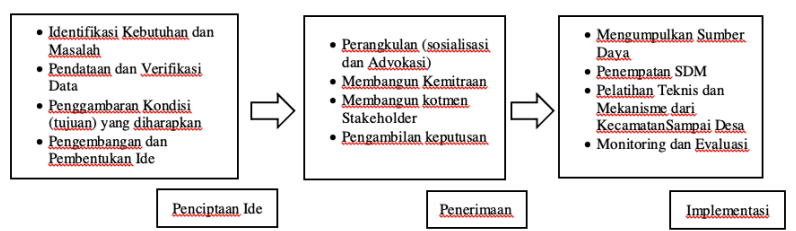

Sumber : Hasil Olahan Data Penelitian, 2020

\section{KESIMPULAN}

Program Inovasi RASKIN Pola PKP merupakan program strategis bagi Dinas Pertanian Kabupaten Timor Tengah Utara. Inovasi Raskin POLA PKP ini bagian dari upaya yang dilakukan pemerintah daerah untuk memaksimalkan pengelolaan lahan kering dan lahan basah dengan menggantikan pembagian raskin menggantikan sistem ganti kerja melalui pengelolaan lahan pertanan miliki rumah tangga sasaran penerima raskin. Inovasi ini dilakukan melalui tiga tahapan, Inovasi ini dilakukan melalui tiga tahapan, Pertama, Penciptaan Ide (generation) terdiri dari Identifikasi Kebutuhan/Masalah, Pendataan, verifikasi Data, Penggambaran Kondisi (tujuan) yang diharapkan Pengembangan dan Pembentukan Ide. Tahap Kedua yaitu Penerimaan (acceptance) terdiri dari Perangkulan (sosialisasi/Advokasi), Membangun 
Kemitraan, Membangun komitmen

Stakeholder dan Pengambilan keputusan selanjutnya pada tahap Ketiga adalah Implementasi (implementation) dari

\section{REFERENSI}

Anggraini, Tri; Seran, M. (2020). Inovasi Birokrasi Pelayanan Publik - Program Raskin Pola Padat Karya Pangan (RASKIN POLA PKP) di Kabupaten Timor Tengah Utara. Journal of Goverment and Political Studies, 3(2). https://doi.org/10.32662/gjgops.v3i2. 1118

Anggraini, T. (2019). Inovasi Birokrasi Pelayanan Publik di Dinas Penanaman Modal dan Pelayanan Terpadu Satu Pintu (Dpmptsp) di Kabupaten Musi Banyuasin Studi Kasus : (Siap Antar Jemput Izin Mudah Berbantuan (SAJI MUBA)). Politeia: Jurnal Ilmu Politik. https://doi.org/10.32734/politeia.v11i 2.1122

Bland et al. (2010). Enhancing Public Sector Innovation: Examining the Network-Innovation Relationship. The Public Sector Innovation Journal, 15(3), 1-17.

Bungin, B. (2007). Penelitian Kualitatif: komunikasi, Ekonomi, kebijakan Publik, dan Ilmu Sosial lainny. Kencana.

Creswell, J. (2014). Research Design: Qualitative, Quantitative, and Mixed Methods Approaches. 4th Edition. The New Zealand Dental Journal, (Vol. 86).

Luthans. (2012). Perilaku Organisasi.
Mengumpulkan Sumber Daya, Penempatan SDM, Pelatihan Teknis/Mekanisme dari Kecamatan sampai desa serta Monitoring dan Evaluasi.

MENPANRB, H. (2018). Kementerian PANRB Tetapkan Top 40 Inovasi Pelayanan Publik 2018. Kementerian Pendayagunaan Aparatur Negara Dan Reformasi Birokrasi.

Miles B, Mathew, \& M. H. (1992). Analisis Data Kualitatif Buku Sumber Tentang Metode-metode Baru. UIP.

Mulgan, G., \& Albury, D. (2003). Innovation in The Public Sector. http://www.sba.oakland.edu/faculty/ mathieson/mis524/resources/readings /innovation/innovation_in_the_public _sector.pdf

Sorensen, E., \& Torfing, J. (2011). Enhancing collaborative innovation in the public sector. Jurnal Administration \& Society, 43(8), 842868.

Subarsono. (2005). Analis Kebijakan Publik. Pustaka Pelajar.

Wahyuni. (2000). Pemberdayaan Kelembagaan Mayarakat Tani Mendukung Percepatan Adopsi dan Keberlanjutan Adopsi Teknologi Usahatani Lahan Rawa. Badan Litbang Pertanian. 